- A Mestre Clarinda Serdeira da Costa Almeida defendeu a sua Dissertação de Mestrado subordinada ao tema "Marketing das Cidades. Caso de Estudo do desenvolvimento da Cidade de Viseu". A tese foi orientada pelo Prof. Doutor António Robalo. As provas realizaram -se em 2004 no ISCTE

\title{
TESES DEFENDIDAS NO IUDPS
}

No âmbito dos mestrados leccionados no IUDPS foram defendidas as seguintes Teses:

- “O ensino privado e a crise do estado-educador" de Jorge Ferreira Cotovio,

- "O ciberespaço como meio de comunicação das organizações escolares" de Filipe Manuel Mota Neves Lima,

- "Associativismo parental. Participação na direcção das políticas educativas nas Escolas" de Armando José dos Santos Almeida,

- "A construção da autonomia das escolas. Análise de um percurso" de Luís João de Figueiredo,

- “Conflitos, negociação e autonomia da escola" de Maria Leonor de Mello Bandeira Corte-Real,

- "A intervenção municipal na educação. O caso do Município de Resende" de Alberto de Jesus Almeida,

- "Percepção dos professores do Ensino Superior Politécnico sobre as suas tarefas e actividades académicas" de João Augusto da Fonseca Brás,

- "O professor dirigente numa Escola Pública à procura de autonomia. Uma perspectiva segundo o Direito Administrativo" de Rosa Maria Pereira de Carvalho,

- "Ensino Básico: formação integral do aluno ou mera adição de disciplinas" de Carlos Manuel Martins Correia,

- "Governação das Escolas. Concepções e representação da Acção dos Conselhos Executivos" de Maria Inês Mateus Ribeiro de Campos,

- “Autonomia das escolas. Papel, dinâmicas e lógicas de acção das Assembleias de Escola" de Manuel Baptista Figueiredo Ribeiro,

- "Municípios e Escolas. Convergências e Tensões" de António João Pinto Bernardo Ferreira, 
- “A Gestão Flexível do Currículo e a Autonomia das Escolas" de Lúcia Pereira de Almeida,

- "Os agrupamentos verticais e a construção da autonomia das escolas" de António Beato Serra,

- "Os professores dos Centros Educativos do Instituto de Reinserção Social: Que formação? de Ana Maria Luciana Gomes Gouveia 